\title{
Phytochemical screening, antibacterial and antioxidant assessment of Leuconotis eugenifolia leaf extract
}

\author{
PRAPTIWI $^{1, \bullet}$, DEWI WULANSARI ${ }^{2}$, AHMAD FATHONI ${ }^{2}$, NOTO HARNOTO ${ }^{3}$, ROSSI NOVITA ${ }^{4}$, \\ ALFRIDSYAH ${ }^{4}$, ANDRIA AGUSTA, ${ }^{1, \vartheta}$ \\ ${ }^{1}$ Research Center for Biology, Indonesian Institute of Sciences. Jl. Raya Jakarta-Bogor Km. 46, Cibinong, Bogor 16911, West Java, Indonesia. \\ Tel./fax.: +62-21-8765066, "email: praptiwip@yahoo.com; ${ }^{\text {v }}$ andr002@lipi.go.id \\ ${ }^{2}$ Research Center for Chemistry, Indonesian Institute of Sciences. Kawasan Puspitek Serpong, Tanggerang Selatan 15314, Banten, Indonesia \\ ${ }^{3}$ Sekolah Tinggi Teknologi Industri dan Farmasi Bogor. Jl. Kumbang 23, Bogor 16151, West Java, Indonesia \\ ${ }^{4}$ Politeknik Kesehatan Kemenkes Aceh. Jl. Soekarno Hatta, Kampus Terpadu Poltekkes Kemenkes Aceh, Lampeuneurut, Aceh Besar 23352, Aceh, Indonesia
}

Manuscript received: 11 May 2020. Revision accepted: 31 May 2020.

\begin{abstract}
Praptiwi, Wulansari D, Fathoni A, Harnoto N, Novita R, Alfridsyah, Agusta A. 2020. Phytochemical screening, antibacterial and antioxidant assessment of Leuconotis eugenifolia leaf extract. Nusantara Bioscience 12: 79-85. Traditionally, sitahe (Leuconotis eugenifolia (Wall. Ex G. Don) A.DC) has been used to maintain stamina by Aceh peoples, Indonesia. The use of L. eugenifolia mainly as a spice on a traditional cuisine "ie bu peudah". This research was conducted to determine the phytoconstituents of L. eugenifolia leaf extracts, and to investigate their antioxidant potential using 2,2-diphenyl-1-picrylhydrazyl (DPPH) scavenging and antibacterial activity against Staphylococcus aureus and Escherichia coli. Phytochemical screening was carried out using standard methods. L. eugenifolia leaves were extracted successively with n-hexane, dichloromethane, ethyl acetate, methanol, and water. Obtained extracts were tested qualitatively for antioxidant and antibacterial by the TLC-bioautography method, followed by quantitative analysis to determine the MIC and IC 50 value using the microdilution method on 96-well microplate. The results showed that it contained alkaloids, flavonoids, steroids, triterpenoids, saponins, phenolics, and tannins. The highest levels of phenolic (259.0486 $\pm 0.1203 \mathrm{mg}$ GAE/g extract) and flavonoids $(84.6575 \pm 0.0237 \mathrm{mg}$ QE/g extract) were found in ethyl acetate extract, and dichloromethane, respectively. The antibacterial activity of $n$-hexane and dichloromethane extracts is moderate against $E$. coli, and weak against $S$. aureus. Ethyl acetate extract, methanol, and water extracts have very strong antioxidant activity. L. eugenifolia leaf extracts may be promising new antioxidant sources.
\end{abstract}

Keywords: Antibacterial, antioxidant, Leuconotis eugenifolia, microdilution, TLC-bioautography

\section{INTRODUCTION}

Plants have been used in various aspects of human life, including in the health sector. Until now, around $80 \%$ of the population still depend on traditional medicinal plants for primary health care. Although there has been a lot of research on medicinal plants, to date the plant is considered a valuable source of chemical compounds for the development of various drugs for various diseases (Angiollela et al. 2018). Traditional medicines in the form of plant extracts have been proven to be clinically effective and relatively less toxic (Awaad 2011).

Chemical ingredients that play a role in bioactivity as a medicinal ingredient include: alkaloids, phenolics, flavonoids, tannins, quinones, saponins, and terpenoids. Alkaloids act as plant protection against pathogens and herbivores and CNS stimulants (Mousavi et al. 2018). Tannins have been used as antidiarrheal and antihemorrhagic (Yogesh and Mala 1998). Phenolic and flavonoids have been known to have many health benefits, can prevent and cure many diseases and are well-known as antioxidants (Tungmunnithum et al. 2018).

The emergence of antibiotic-resistant bacteria has been dramatically increased. Antibiotic-resistant bacteria cause at least 2 million infections and 23,000 deaths per year in the USA (Li and Webster 2017). Therefore, there is a need for new, effective, affordable for treating microbes infections and to overcome antibiotic-resistant bacteria (Elisha et al. 2017).

Oxidative stress is characterized by an imbalance between the production of reactive oxygen species (ROS) and antioxidant activity, and the increase can lead to several chronic diseases such as cancer, diabetes, neurodegenerative and cardiovascular disease (Angilella et al. 2018). ROS in the biological system can damage DNA and oxidation of lipid and protein in the cells (Peng et al. 2014). The antioxidant system in the human body can scavenge ROS and keep the balance between oxidation and antioxidation ( $\mathrm{Xu}$ et al 2017).

Sitahe (Leuconotis eugenifolia) has been used to strengthen stamina by the people of Aceh, Indonesia. This plant species distributed in Sumatra, Kalimantan, and Peninsular Malaysia and secondary metabolites vary depending on the place of growth (Tang et al. 2019). To the best of our knowledge, publications on L. eugenifolius collected from Indonesia are still very limited. Abe and Yamauchi (1993) have reported that L. eugenifolia from Sumatra, Indonesia without specifying a more specific location contains 6 types of indole alkaloids ie. yohimbine, $\beta$-yohimbine, leukonolam, 21-O-leuconolam, diazaspirolukonolam, and rhazinalin-N6-oxide. These secondary metabolites did not found in plant samples 
collected from the Peninsular area (Gih et al. 1989; Gan 2009a, b; Deguchi et al. 2010; Tang et al. 2019). Variations in secondary metabolites could produce different biological activities of the plant extract. Therefore, this study aims to determine the phytochemical compounds, antibacterial, and antioxidant activity of sitahe (Leuconotis eugenifolia) collected from Aceh, Indonesia.

\section{MATERIALS AND METHODS}

\section{Collection and preparation of plant material}

Leuconotis eugenifolia leaves were collected from Aceh. The plant was identified at the Herbarium Bogoriense (BO), Research Center for Biology, Indonesian Institute of Sciences, Cibinong, Bogor, Indonesia. The leaves were washed and air-dried followed by grinding the sample.

\section{Preparation of extracts: maceration}

Leuconotis eugenifolia leaves powder was macerated for 3 days and stirred occasionally. Ethanol $70 \%$ was used as an extractant using a ratio of 1: 10 of L. eugenifolia leaves to ethanol $70 \%$. The extraction process is done 3 times. The filtrate was collected and then concentrated with a rotary evaporator to get concentrated extract. The concentrated extract was partitioned using the different polarity of solvents, i.e., $n$-hexane, dichloromethane, ethyl acetate, methanol, and water.

\section{Phytochemical screening}

Phytochemical content of L. eugenifolia leaf extract was analyzed qualitatively according to the standard method as follows:

Test for alkaloid. $1.5 \mathrm{~mL}$ of extract was added with 2 $\mathrm{mL}$ of $\mathrm{HCl} 2 \%$. To this mixture was added with Mayer reagent and the formation of a white precipitate indicates the presence of alkaloid. At the addition of Dragendroff, the presence of alkaloids was indicated by the presence of orange or orange-red precipitate.

Test for glycoside. $1 \mathrm{~mL}$ of extract was dissolved in ethanol followed by heat- evaporation. Then, it dissolved in $1 \mathrm{~mL}$ of anhydrous acetic acid and added 5 drops of concentrated sulfuric acid. Blue or green color indicates the presence of glycosides.

Test for steroids and terpenoids. The extract was dissolved in $0.5 \mathrm{~mL}$ chloroform, add $0.5 \mathrm{~mL}$ anhydrous acetic acid. This mixture was added with $2 \mathrm{~mL}$ of concentrated sulfuric acid through the tube wall. Green color indicating the presence of sterols, while brownish ring indicating the presence of triterpenes.

Test for saponin. $1.5 \mathrm{~mL}$ of extract in the test tube was shaken. The presence of saponin indicated by foam formation as high as $1 \mathrm{~cm}$ that persistent for 15 minutes.

Test for polyphenol and tannin. 1-1.5 mL of extract was added with $1 \mathrm{~mL}$ of $10 \% \mathrm{FeCl}_{3}$ solution. The presence of dark blue, black-blue, or greenish-black color indicated the presence of polyphenol and tannin.

Test for flavonoid. $1.5 \mathrm{~mL}$ of extract added with magnesium powder, then heated followed by the addition of concentrated $\mathrm{HCl}$. Positive results indicated by the presence of red color in the extract solution.

\section{Determination of Total Phenolic Content (TPC)}

Total phenolic content (TPC) was carried out by Folin Ciocalteu's method. Two hundred $\mu \mathrm{L}$ extract (1000 $\mu \mathrm{g} / \mathrm{mL}$ ) and standard gallic acid at the concentration range of $6.25-200 \mu \mathrm{g} / \mathrm{mL}$ added $0.2 \mathrm{~mL}$ of $50 \%$ Folin-Ciocalteu solution and vortex for 1 minute. The mixture was added 4 $\mathrm{mL}$ of $2 \%$ sodium carbonate $\left(\mathrm{Na}_{2} \mathrm{CO}_{3}\right)$ solution then incubated under dark at room temperature for 30 minutes. The absorbance of the extract was read at a wavelength of $750 \mathrm{~nm}$ using a UV-Vis spectrophotometer and performed in triplicates. The results are expressed as $\mathrm{mg}$ gallic acid/g extract (Ismail et al. 2012).

\section{Determination of Total Flavonoid Content (TPC)}

$0.5 \mathrm{~mL}$ extract $(1000 \mu \mathrm{g} \mathrm{mL})$ and standard quercetin at the concentration range of $3.125-100 \mu \mathrm{g} \mathrm{mL}$ each added with 1.5 ethanol pa, $0.1 \mathrm{~mL} 10 \% \mathrm{AlCl} 3,0.1 \mathrm{~mL}$ $\mathrm{CH}_{3} \mathrm{COONa} .3 \mathrm{H}_{2} 1 \mathrm{M}$ and $2.8 \mathrm{~mL}$ aquabidest. The mixture was incubated at room temperature for 30 minutes under dark conditions. The absorbance of the extract solution is read at a wavelength of $417 \mathrm{~nm}$ with a UV-Vis spectrophotometer (UVmini-1240, Shimadzu) and performed in triplicates. The results are expressed as mg quercetin/g extract (Pourmorad et al. 2006).

\section{Detection of antibacterial activity by TLC-Direct bioautography}

TLC-direct bioautography for antibacterial activity was carried out by the dot-blot method and developed TLCplates aseptically. The antibacterial activity of extracts was carried out against Escherichia coli Ina-CC B5 and Staphylococcus aureus B4. Dot-blot method: Ten $\mu \mathrm{L}$ of extract $(10 \mu \mathrm{g} / \mathrm{mL})$ was transferred onto silica TLC-plate (Merck, silica gel 60 F254) and air-dried. Chloramphenicol was used as a positive control, while the solvent used as the negative control. Developed-TLC plates: The extracts were developed with eluent system as follows: hexane extract was developed with eluent system of hexane: ethyl acetate (3: 1), dichloromethane and ethyl acetate extracts were developed with dichloromethane: methanol (10: 1), while methanol and water extracts were developed with chloroform: methanol: water (6: 4: 1). After finish transferring and developing the extracts, TLC-plate were dipped in the bacterial suspension, and then incubated for $18-24$ hours at $37^{\circ} \mathrm{C}$ under humid condition by adding sterile wet-cotton. After incubation, plates were sprayed with iodonitrotetrazolium (4 mg/mL) aqueous solution. Growth inhibition was indicated by white zones against the purple background.

\section{Detection of antioxidant activity by TLC-direct bioautography}

TLC-direct bioautography for antioxidant activity was carried out by the dot-blot method and developed TLCplates. The antibacterial activity of extracts was carried out against E. coli and S. aureus. Dot-blot method: Ten $\mu \mathrm{L}$ of extract $(10 \mu \mathrm{g} / \mathrm{mL})$ was transferred onto silica TLC-plate 
(Merck, silica gel 60 F254) and air-dried. Developed-TLC plates: The extracts were developed with eluent system as follows: hexane extract was developed with eluent system of hexane: ethyl acetate (3: 1), dichloromethane and ethyl acetate extracts were developed with dichloromethane: methanol (10: 1), while methanol and water extracts were developed with chloroform: methanol: water $(6: 4: 1)$. The plates were sprayed with $0.2 \%$ DPPH (2,2-diphenyl-1picrylhydrazyl) solution in methanol. The yellow color against purple background indicated active antioxidant extract or compounds.

\section{Determination of Minimum Inhibitory Concentration (MIC) \\ Determination of Minimum Inhibitory Concentration} (MIC) was performed by broth microdilution in 96-well microplate against $E$. coli and $S$. aureus. The extract concentrations for determining MIC value were in the range of 2-256 $\mu \mathrm{g} / \mathrm{mL}$. Positive control chloramphenicol ranges from 2 to $32 \mu \mathrm{g} / \mathrm{mL}$.

The first well in row A was introduced with $100 \mu \mathrm{L}$ of Mueller Hinton Broth (MHB), $10 \mu \mathrm{L}$ of extract (1024 $\mu \mathrm{g} / \mathrm{mL}$ ), and $90 \%$ sterile aqua dest. The following row was introduced with $100 \mu \mathrm{L}$ of MHB (row B-H). Twofold dilution was carried out as follows: one hundred $\mu \mathrm{L}$ was removed from row A and transferred to the next column in the same row and mixed properly. It was repeated to the last row. In the last row, $100 \mu \mathrm{L}$ was discarded. After finish dilution, bacterial suspension $\left(10^{5} \mathrm{CFU} / \mathrm{mL}\right)$ was added into each well. The microplate was incubated at $37^{\circ} \mathrm{C}$ for 24 hours. After incubation, each well of microplate was added with $10 \mu \mathrm{L}$ of INT $(4 \mathrm{mg} / \mathrm{mL})$ and incubated for a few minutes. The inhibition of bacterial growth can be observed by changes in the color of the wells. The lowest concentration of well with no color change was determined as MIC value.

\section{Determination of $\mathrm{IC}_{50}$ for antioxidant activity}

IC50 for antioxidant of the extract was carried out by two-fold microdilution in the 96-well microplate. Catechin was used as a positive control. The first row (A) was introduced with $195 \mu \mathrm{L}$ methanol and $5 \mu \mathrm{L}$ extract $(1024$ $\mu \mathrm{g} / \mathrm{mL})$, mixed properly. Each well on the next row was introduced with $100 \mu \mathrm{L}$ methanol. One hundred $\mu \mathrm{L}$ of the $1^{\text {st }}$ row was transferred into the $2^{\text {nd }}$ at the same column and mixed properly. It was repeated up to the last row, and 100 $\mu \mathrm{L}$ was discarded from the last row. After finish dilution, $100 \mu \mathrm{L}$ DPPH $(61.5 \mathrm{mg} / 50 \mathrm{~mL})$ was added into each well. The microplate was incubated at room temperature for 90 min under dark conditions. After incubation, the absorbance was recorded at $517 \mathrm{~nm}$ wavelength with a microplate reader (Varioskan Flash). Percent inhibition concentration (IC) was calculated as follows:

$$
\text { IC }(\%)=\left(\frac{A_{\text {control }}-A_{\text {sample }}}{A_{\text {control }}}\right) \times 100 \%
$$

Where; A control is the absorbance of DPPH without samples, A sample is the absorbance of DPPH along with different concentrations of extracts. The $\mathrm{IC}_{50}$ values of
DPPH were obtained from linear calibration between the percentage of inhibition and sample concentration. The antioxidant activity index (AAI) acquired by the formula below:

$$
\text { AAI }=\frac{\text { The final concentration of DPPH }}{I_{50}}
$$

\section{Statistical analysis}

Statistical analysis of variance of total phenolic contents (TPC) and total flavonoid contents (TFC) values was performed by Duncan's Multiple- Range Tests using SPSS 16.0. The experiment was performed in triplicate and expressed as mean \pm SD. Values in each column with the different letters are significantly different $(\mathrm{P}<0.05)$.

\section{RESULTS AND DISCUSSION}

\section{Phytochemical content of sitahe leaf extract}

Phytochemical screening of L. eugenifolia leaf extracts in various organic solvents showed the presence of alkaloid, flavonoid, steroid, triterpenoid, saponin, phenolic, and tannin, although some chemical compounds were absent in some extracts (Table 1). It showed that some of the chemical compounds are absent, i.e. triterpenoid was absent in $n$-hexane, dichloromethane, and ethyl acetate extracts.

\section{Estimation of Total Phenolic Content (TPC) and Total Flavonoid Content (TFC)}

The total phenolic content (TPC) and total flavonoid content (TFC) were presented in Table 2. Total phenolic contents were ranging from 4.9931 to $259.0486 \mathrm{mg} \mathrm{GAE} / \mathrm{g}$ extract, while TFC were ranging from 9.1691 to 84.6575 $\mathrm{mg} \mathrm{QE} / \mathrm{g}$ extract. The results showed that the highest TPC was in the ethyl acetate extract $(259.0486 \pm 0.1203 \mathrm{mg}$ GAE/g extract), while the highest TFC was in the dichloromethane extract $(84.6575 \pm 0.0237 \mathrm{mg} \mathrm{QE} / \mathrm{g}$ extract). Total phenolic contents and total flavonoids contents of L. eugenifolia leaf were solvent dependent

Table 1. Phytoconstituents of Leuconotis eugenifolia leaf extracts

\begin{tabular}{|c|c|c|c|c|c|}
\hline \multirow[b]{2}{*}{$\begin{array}{l}\text { Chemical } \\
\text { compounds }\end{array}$} & \multicolumn{5}{|c|}{ Extract } \\
\hline & 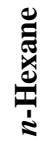 & 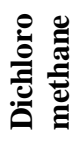 & 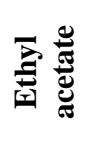 & 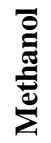 & $\frac{\bar{d}}{3}$ \\
\hline Alkaloid & + & + & + & + & + \\
\hline Flavonoid & - & + & + & + & + \\
\hline Steroid & + & + & + & - & + \\
\hline Triterpenoid & - & - & - & + & - \\
\hline Saponin & - & - & - & - & + \\
\hline Phenolic & + & + & + & + & + \\
\hline Tannin & - & - & + & + & + \\
\hline Glycoside & - & - & - & - & - \\
\hline
\end{tabular}
in various solvents

Note: +: present, -: absent 


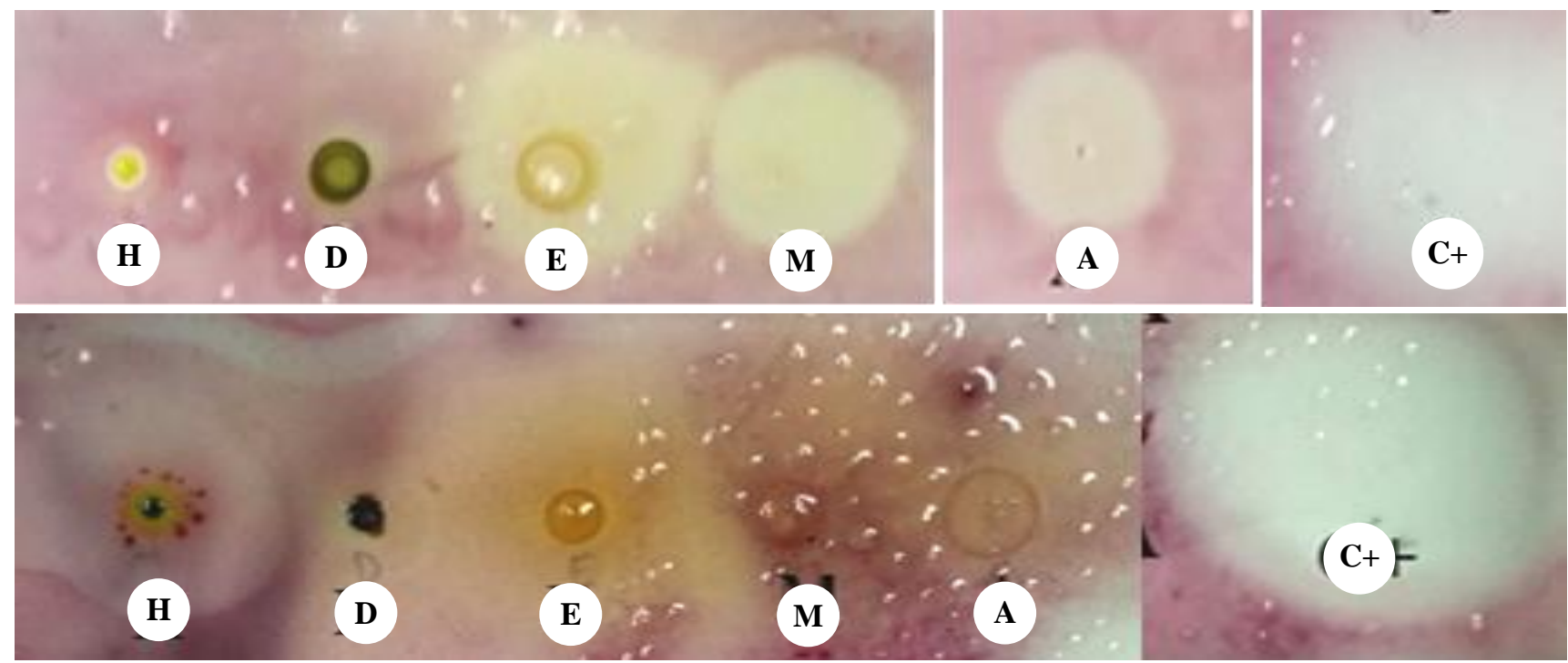

Figure 1. Dot-Blot Test for antibacterial activity of Leuconotis eugenifolia leaf extract against Staphylococcus aureus (top) and Escherichia coli (bottom), extract of: H: n-Hexane; D: Dichloromethane; E: Ethyl Acetate; M: Methanol; A: Water, and C+: Chloramphenicol
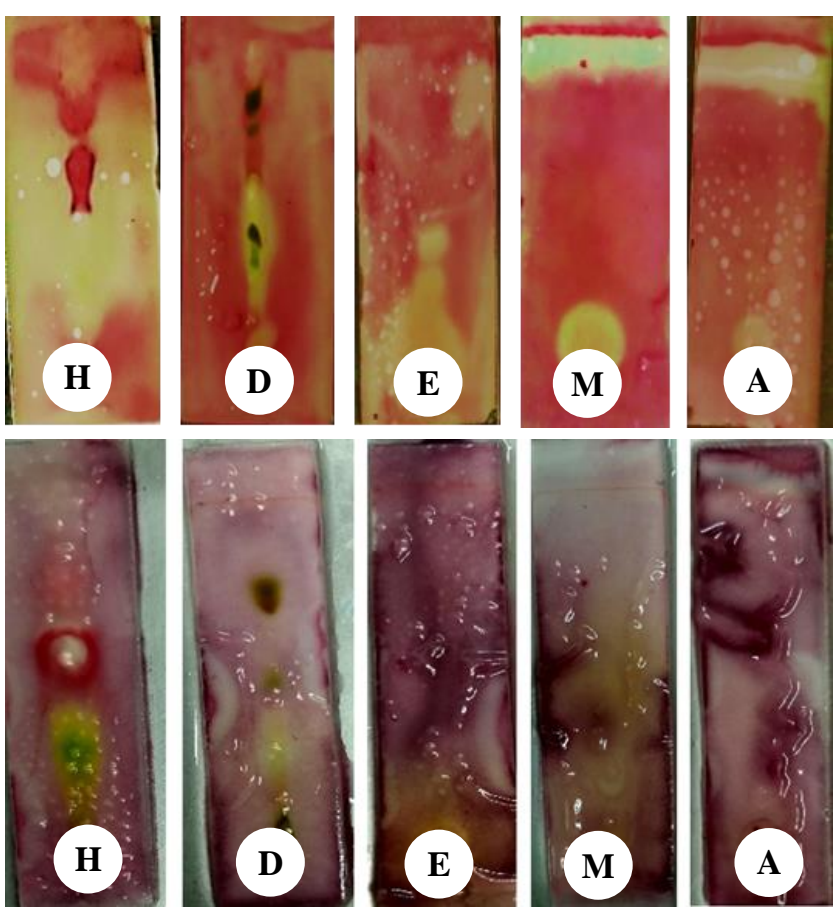

Figure. 2. TLC-Bioautogram for antibacterial activity of Leuconotis eugenifolia leaf extract against Staphylococcus aureus (top) and Escherichia coli (bottom). H: n-Hexane; D Dichloromethane; E: Ethyl Acetate; M: Methanol; and A: Water

\section{TLC-Bioautography for antibacterial assay}

Antibacterial activity of L. eugenifolia leaf extracts was performed by the Dot-Blot method (Figure 1) and Developed Plates (Figure 2). Dot-Blot method for antibacterial activity against $S$. aureus showed that ethyl acetate, methanol, and water extracts have wider yellowishwhite spots compared to hexane and dichloromethane extract.
Table 2. Total phenolic content (TPC) and Total flavonoid content (TFC) of Leuconotis eugenifolia leaf extract

\begin{tabular}{lll}
\hline Extract & $\begin{array}{l}\text { TPC } \\
\text { (mg GAE/g } \\
\text { extract) }\end{array}$ & $\begin{array}{l}\text { TFC } \\
(\mathbf{m g ~ Q E} / \mathbf{g} \text { extract) }\end{array}$ \\
\hline$n$-Hexane & $4.9931^{\mathrm{e}} \pm 0.0120$ & $9.1691^{\mathrm{e}} \pm 0.0079$ \\
Dichloromethane & $88.5903^{\mathrm{d}} \pm 0.0241$ & $\mathbf{8 4 . 6 5 7 5}^{\mathrm{a}} \pm \mathbf{0 . 0 2 3 7}$ \\
Ethyl acetate & $\mathbf{2 5 9 . 0 4 8 6}^{\mathrm{a}} \pm \mathbf{0 . 1 2 0 3}$ & $62.9817^{\mathrm{b}} \pm 0.0079$ \\
Methanol & $133.2153^{\mathrm{c}} \pm 0.0241$ & $30.7808^{\mathrm{d}} \pm 0.0362$ \\
Water & $164.2083^{\mathrm{b}} \pm 0.0361$ & $37.0228^{\mathrm{c}} \pm 0.0174$ \\
\hline
\end{tabular}

Note: Each value was represented by mean \pm SD $(n=3)$. Values in the same column with different letters are significantly different $(\mathrm{P}<0.05)$

The developed plates of antibacterial activity of $L$. eugenifolia leaf extract against $S$. aureus and E. coli showed white bands that indicated the presence of bioactive chemical compounds in the extracts.

\section{Determination of Minimum Inhibitory Concentration}

Minimum Inhibitory Concentration of extracts was carried out by microdilution in 96-well microplate. The results showed that ethyl acetate extract has moderate antibacterial activity against $S$. aureus, while hexane and dichloromethane extracts have moderate antibacterial activity against $E$. coli. The MIC of the extracts against $E$. coli and S. aureus ranged $256->256 \mu \mathrm{g} / \mathrm{mL}$.

\section{Antioxidant activity of si Tahe leaf extracts}

TLC-bioautography for antioxidant either by Dot-Blot or Developed Plates showed the formation of yellowish spots or bands indicated antioxidant activity. The developed plates (Figure 4) showed several yellow spots indicated the chemical compounds possess antioxidant activity. 
Table. 3. Minimum inhibitory concentration (MIC) of Leuconotis eugenifolia leaf extract against Staphylococcus aureus and Escherichia coli

\begin{tabular}{lllll}
\hline \multirow{2}{*}{ Extract } & \multicolumn{4}{c}{ MIC $(\boldsymbol{\mu g} / \mathbf{m L})$} \\
\cline { 2 - 5 } & \multicolumn{1}{c}{$\boldsymbol{S}$ aureus } & Category & $\begin{array}{c}\boldsymbol{E} . \\
\text { coli }\end{array}$ & Category \\
\hline$n$-Hexane & ND & - & 256 & Moderate \\
Dichloromethane & ND & - & 256 & Moderate \\
Ethyl acetate & 256 & Moderate & $>256$ & Weak \\
Methanol & $>256$ & Weak & $>256$ & Weak \\
Water & $>256$ & Weak & $>256$ & Weak \\
Chloramphenicol & 16 & Strong/good & 16 & Strong/good \\
\hline
\end{tabular}

Note: ND = Not determined

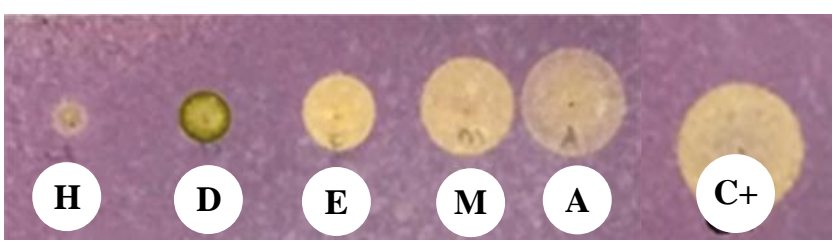

Figure 3. Dot-blot test for DPPH free radical scavenging (antioxidant) activity of Leuconotis eugenifolia leaf extract. H: nhexane, D: dichloromethane, E: ethyl acetate, M: methanol, A: water, $\mathrm{C}+$ : catechin

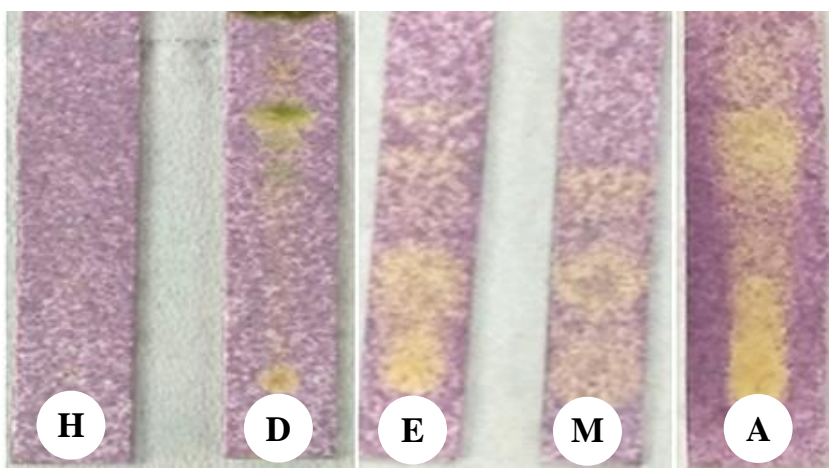

Figure 4. TLC-bioautogram for antioxidant activity of Leuconotis eugenifolia leaf extracts. H: $n$-hexane, D: dichloromethane, E: ethyl acetate, M: methanol, A: water

Table 4. The $\mathrm{IC}_{50}$ value for antioxidant activity and antioxidant activity index (AAI) of Leuconotis eugenifolia leaf extracts

\begin{tabular}{|c|c|c|c|}
\hline Extract & $\begin{array}{c}\mathrm{IC}_{50} \\
(\mu \mathrm{g} / \mathrm{mL})\end{array}$ & AAI & Category \\
\hline Hexane & NT & NT & - \\
\hline Dichloromethane & NT & NT & - \\
\hline Ethyl acetate & 11.50 & 2.67 & Very strong \\
\hline Methanol & 5.25 & 5.86 & Very strong \\
\hline Water & 11.44 & 2.69 & Very strong \\
\hline Catechin & 2.36 & 13.02 & Very strong \\
\hline
\end{tabular}

Note: ND: not determined. Category of antioxidant activity of the extracts based AAI value (weak $<0.05<$ moderate $<1<$ strong $<$ $2<$ very strong) (Scherer and Godoy 2009)

\section{Determination of $\mathrm{IC}_{50}$ for antioxidant activity by DPPH- method}

Microdilution analysis for antioxidant activity in 96well microplate showed that ethyl acetate, methanol, and water extracts possess very strong antioxidant activity on DPPH- free radical scavenging method.

\section{Discussion}

The medicinal plants are widely used in the primary health-care system. It is due to the phytoconstituents of the plant as the basis for traditional herbal medicine (Govindarajan et al. 2005). Plants are considered natural sources of new compounds of medical and biotechnological interest since they synthesize a large variety of bioactive compounds (Farias et al. 2013).

Phytoconstituents of $L$. eugenifolia leaf extracts extracted in various solvents with different polarity (Table 1) showed that different polarity of solvent extracted different chemical compounds. The chemical compound was extracted optimally in the solvent of the same polarity. Therefore, the solvents are responsible for extracting the chemical compounds of the plants (Siddurhaju and Becker 2003). Phenolic, alkaloid, and tannin present in all extract, however, they may have different molecular structures. Alkaloids are reported to have analgesic, antiinflammatory, and adaptogenic activities which help to alleviate pains developed resistance against disease and endurance against stress (Manhas and Dahiya 2017). Phenolic and flavonoids have several biological activities with health benefits such as antiatherosclerosis, and cardiovascular protection (Batta 2016). Saponins and tannins have anti-inflammatory effects (Shah and Hossain 2014). Tannin also can bind proline-rich protein (Ahmed et al 2014). Therefore, the phytochemical constituents of $L$. eugenifolia leaf extract may have biological activities.

The leaf extracts of $L$. eugenifolia were tested for antibacterial activity against $S$. aureus and $E$. coli by Direct TLC-bioautography method due to its fast, inexpensive, and simple and easy. TLC-bioautography enables rapid detection for antimicrobial activity of the extract and allows the localization of antimicrobial activity directly on the chromatographic plate (Navarro et al. 1998). The TLC bioautographic method combines chromatographic separation and determination of in situ activities that facilitate localization and target-directed isolation of active constituents in the mixture (Shahverdi et al. 2007).

In the TLC-bioautography test, antibacterial activity was demonstrated by the appearance of a white area with a purple-red background on the chromatogram. Living microorganisms can reduce INT to a purple-red color (Begue and Klein 1972). Based on the white area formation, it showed that ethyl acetate, methanol, and water extracts inhibit the growth of S. aureus, while E. coli was inhibited by ethyl acetate. The eluted plate showed several spots that indicated the active components of the extract. Although in the TLC-Bioautography results showed there were yellowish-white several spots or white bands on $L$. eugenifolia leaf extracts indicated the capability of extracts to inhibit the growth of S. aureus or 
E. coli, however the MIC value of extracts categorized as weak to moderate antibacterial activity.

Antioxidant activity of $L$. eugenifolia leaf extracts was carried out by the TLC-bioautography assay with DPPH reagent. DPPH is a stable free radical that is mostly used technique to evaluate antioxidant activity due to its quick, easy and simple test (Dudonne et al. 2009; Ali et al. 2013). Antioxidative compounds change the purple color of DPPH to yellow because the antioxidant compounds scavenge the DPPH free radicals (Ali et al. 2013). The dot-blot method and eluted plate showed that ethyl acetate, methanol, and water extracts possess antioxidant activity.

Ethyl acetate, methanol, and water extracts have very strong antioxidant activity. There was a correlation between total phenolic compounds (TPC) with $\mathrm{IC}_{50}$ of the extract. Phenolic compounds are important chemical components in plants because they are redox which is responsible for antioxidant activity (Soobrattee et al. 2005). Phenolics can donor electrons and their hydroxyl group contribute to the antioxidant activity (Bendary et al. 2013). The results showed that different solvent results in different antioxidant activity. It is suggested that different solvents with different polarity extracted different chemical compounds.

The content of phenolic and flavonoid compounds in $L$. eugenifolia leaves is quite high. Compounds from this group are generally well known to have a positive effect on blood circulation in the body, including improving blood flow in the brain (Rees et al. 2018). Therefore, it is suspected that the high content of flavonoid and phenolic groups in L. eugenifolia leaves play an important role in restoring stamina by consuming "ie bu peudah" in the people of Aceh. The yohimbine alkaloid, known as aphrodisiacs (Ostojic 2006), may also play an important role in strengthening stamina, but in-depth studies are still needed.

To conclude, the results of the study showed that $L$. eugenifolia leaves have a high content of flavonoids and phenolics, and several other classes of compounds such as alkaloids. L. eugenifolia leaf extract showed good potential as an antioxidant, but moderate and weak antibacterial activity against $E$. coli Ina-CC B5 and $S$. aureus Ina-CC B4. Isolation of active constituents is ongoing.

\section{ACKNOWLEDGEMENTS}

This study was funded by the DIPA Indonesian Institute of Sciences. The authors declare no conflict of interest

\section{REFERENCES}

Abe F, Yamauchi T. 1993. Indole alkaloids from leaves and stems of Leuconotis eugenifolius. Phytochemistry 35 (1): 169-171.

Ahmed AS, McGaw LJ, Elgorashi EE, Naidoo V, Eloff JN. 2014. Polarity of extracts and fractions of four Combretum (Combretaceae) species used to treat infections and gastrointestinal disorders in southern African traditional medicine has a major effect on different relevant in vitro activities. J Ethnopharmacol 154 (2): 339-350.

Ali HM, Salem MZM, Al Sahli AA. 2013. Performance of antioxidant activity of methanolic extracts from different parts of some tree species using DPPH radical-scavenging assay. J Pure Appl Microbiol 7: 131-137.

Angiolella L, Sacchetti G, Efferth T. 2018. Antimicrobial and antioxidant activities of natural compounds. Evid-Based Compl Altern Med 2018: 1945179. DOI: 10.1155/2018/1945179.

Awaad AS, El-Meligy RM, Qenawy SA, Atta AH, Soliman GA. 2011. Anti-inflammatory, antinociceptive and antipyretic effects of some desert plants. J Saudi Chem Soc 15 (4): 367-373.

Batta A. 2016. A review on phytochemicals and their activities. Intl J Res Med Sci 2 (1): 20-28.

Begue WJ, Klein RM. 1972. The use of tetrazolium salts in bioautographic procedure. J Chromat 88: 182-184.

Bendary E, Francis RR, Ali HMG, Sarwat MI, El Hady S. 2013.Antioxidant and structure-activity relationships (SARs) of some phenolic and anilines compounds. Ann Agric Sci 58: 173-181.

Deguchi J, Shoji T, Nugroho AE, Hirasawa Y, Hosoya T, Shirota O, Awang K, Hadi HA, and Morita H. 2010. Eucophylline, a tetracyclic vinylquinoline alkaloid from Leuconotis eugenifolia. J Nat Prod 73: 1727-1729.

Dudonné S, Vitrac X, Coutiere P, Woillez M, Mérillon J.-M. 2009. Comparative study of antioxidant properties and total phenolic content of 30 plant extracts of industrial interest using DPPH, ABTS, FRAP, SOD, and ORAC assays. J Agric Food Chem 57: 1768-1774.

Elisha IL, Botha FS, McGaw LJ, and Eloff JN. 2017. The antibacterial activity of extracts of nine plant species with good activity against Escherichia coli against five other bacteria and cytotoxicity of extracts. BMC Compl Altern Med 17: 133 DOI 10.1186/s12906-017$1645-\mathrm{z}$

Farias DF, Souza TM, Viana MP, Soares BM, Cunha AP, Vasconcelos IM, Ricardo NMPS, PFerreira PMP, Melo VMM, Carvalho AVU. 2013. Antibacterial, antioxidant, and anticholinesterase activities of plant seed extracts from Brazilian Semiarid Region

Gan CY, Low YY, Etoh T, Hayashi M, Komiyama K, Kam TS. 2009. Leuconicines A-G and (-)-Eburnamaline, biologically active strychnan, and eburnan alkaloids from Leuconotis. J Nat Prod 72 (20): 2098-2103.

Gan CY, Robinson WT, Tadahiro Etoh T, Hayashi M, Komiyama K, $\$$ and Kam TS. 2009. Leucophyllidine, a cytotoxic bisindole alkaloid constituted from the Union of an Eburnan and a New Vinylquinoline Alkaloid. Organic Lett 11 (17): 3962-3965.

Goh SH. Ali ARM, Wong WH. 1989. Alkaloids of Leuconotis griffithi and L.eugenifolia (Apocynaceae). Tetrahedron 45 (24): 7899-7920.

Govindarajan R, Vijayakumar M, and Pushpangadan P. 2005. Antioxidant approach to disease management and the role of "Rasayana" herbs of Ayurveda. J Ethnopharmacol 99 (2): 165-178,

Li B, Webster TJ. 2018. Bacteria antibiotic resistance: new challenges and opportunities for implant-associated orthopaedic infections. J Orthop Res 36 (1): 22-32. DOI: 10.1002/jor.23656.

Manhas, N, Dahiya, P. 2017. In vitro antimicrobial activity and phytochemical screening of leaf and stem extracts of Michelia champaca Linn. Intl Food Res J 24 (6): 2672-2676.

Masoko P, Mokgotho MP, Mbazima VG, Mampuru LJ. 2008. Biological activity of Typha capensis (Typhaceae) from Limpopo Province (South Africa). Afr J Biotechnol. 20: 3743-3748.

Mousavi L, Salleh RM, Murugaiyah V. 2018. Phytochemical and bioactive compounds identification of Ocimum tenuiflorum leaves of methanol extract and its fraction with anti-diabetic potential. Intl $\mathbf{J}$ $\begin{array}{llll}\text { Food Propert } 21 & \text { (1): } 2390-2399 . & \text { DOI: }\end{array}$ 10.1080/10942912.2018.1508161

Navarro V, Rojas G, Delgado G, Lozoya X. 1998. Antimicrobial compounds detected in Bocconia arborea extracts by direct bioautographic method. Arch Med Res 29: 191-194.

Ostojic SM. 2006. Yohimbine: The effects on body composition and exercise performance in soccer players. Res Sports Med Intl J 14 (4): 289-299.

Peng C, Wang X, Chen J, Jiao R, Wang L, Li YM, Zuo Y, Liu Y, Lei L, Ma KY, et al. 2014. Biology of ageing and role of dietary antioxidants. BioMed Res Intl 2014: 831841. DOI: 10.1155/2014/831841

Rees A, Dodd GF, Spencer JPE. 2018. The effects of flavonoids on cardiovascular health: a review of human intervention trials and implications for cerebrovascular function. Nutrients 10: 1852. DOI: 10.3390/nu 10121852.

Scherer R, Godoy HT. 2009. Antioxidant activity index (AAI) by the 2,2diphenyl-1-picrylhydrazyl method. Food Chem. 112 (3): 654-658. DOI: 10.1016/j. foodchem.2008.06.026. 
Shah MD, Hossain MA. 2014. Total flavonoids content and biochemical screening of the leaves of tropical endemic medicinal plant Merremia borneensis. Arabian J Chem 7 (6): 1034-1038.

Shahverdi AR, Abdolpour F, Monsef-Esfahani HR, Farsam H. 2007. A TLC bioautographic assay for the detection of nitrofurantoin resistance reversal compound. J Chromat B 850: 528-530.

Siddhuraju P, Becker K. 2003. Antioxidant properties of various solvent extracts of total phenolic constituents from three different agroclimatic origins of drumstick tree (Moringa oleifera Lam.) leaves. J. Agric. Food Chem. 51: 2144-2155.

Soobrattee M.A, Neergheen V.S, Luximon-Ramma A, Aruoma O.I, Bahorun T. 2005. Phenolics as potential antioxidant therapeutic agents: Mechanism and actions. Mutat. Res.-Fund. Mol. Mutagen. 579: $200-213$
Tang Y, Nugroho AE, Hirasawa Y . Tougan T, Horii T. Hadi AHA Morita H. 2019. Leucophyllinines A and B, bisindole alkaloids from Leuconotis eugeniifolia. J Natural Medicines DOI: 10.1007/s11418-019-01297-5

Tungmunnithum D, Thongboonyou A, Pholboon A, Yangsabai A. 2018. Flavonoids and other phenolic compounds from medicinal plants for pharmaceutical and medical aspects: an overview. Medicines (Basel): 5 (3): 93. DOI: 10.3390/medicines5030093

Xu DP, Li Y, Meng X, Zhou T, Zhou Y, Zheng J, Zhang JJ, Li HB. 2017. Natural antioxidants in foods and medicinal plants: extraction, assessment and resources Intl $\mathrm{J}$ Mol Sci 18: 96. DOI: 10.3390/ijms 18010096

Yogesh CT, Rathore M. 1998. Bioactivity and Drug Potential of Tannins. XIX Int. Conf. on Polyphenol. Polyphenol Communication 98 vol. 1. Lille, France. 